\title{
PENGARUH GAYA KEPEMIMPINAN DAN DISIPLIN KERJA TERHADAP KINERJA KEPOLISIAN POLISI SEKTOR (POLSEK) PONDOK AREN
}

\author{
${ }^{1}$ Andri Kurniawan, ${ }^{2 *}$ Isep Amas Priatna \\ Universitas Pamulang, Tangerang Selatan, Banten, Indonesia \\ *dosen01629@unpam.ac.id
}

\begin{abstract}
Abstrak
Tujuan penelitian ini untuk mengetahui pengaruh gaya kepemimpinan dan disiplin kerja terhadap kinerja kepolisian Polisi sektor (Polsek) Pondok Aren. Penelitian ini menggunakan pendekatan kuantitatif dengan populasi sebesar 80 orang. Hasil uji F menyatakan bahwa ada hubungan yang signifikan antara variabel Gaya Kepemimpinan $\left(\mathrm{X}_{1}\right)$ dan Disiplin Kerja $\left(\mathrm{X}_{2}\right)$ terhadap variabel terikat yaitu Kinerja Kepolisian $(\mathrm{Y})$. Hasil uji-t dari kedua variabel independen memiliki nilai koefisien yang signifikan, yaitu terdapat hubungan yang signifikan antara variabel Gaya Kepemimpinan (X1) dan Disiplin Kerja $\left(\mathrm{X}_{2}\right)$ terhadap variabel terikat yaitu variabel Kinerja $(\mathrm{Y})$. Hasil persamaan regresi berganda $Y=8,327+0,433 X 1+0,364 X 2$.
\end{abstract}

Kata Kunci: Gaya Kepemimpinan, Disiplin Kerja dan Kinerja Kepolisian

Abstract

The purpose of this study was to determine the effect of leadership style and work discipline on the performance of the Pondok Aren Sector Police (Polsek). This type of research uses a quantitative approach with a population of 80 people. The results of the F test state that there is a significant relationship between the variable Leadership Style (X1) and Work Discipline (X2) on the dependent variable, namely Police Performance (Y). The $t$-test results of the two independent variables have a significant coefficient value, that is, there is a significant relationship between the Leadership Style (X1) and Work Discipline (X2) variables on the dependent variable, namely the Performance $(Y)$ variable. The result of the multiple regression equation $Y=8.327+0.433 \mathrm{X} 1+$ $0.364 X 2$.

Keywords: leadership style, work discipline and police performance

\section{PENDAHULUAN}

Masalah sumber daya manusia menjadi tantangan tersendiri bagi manajemen pada instansi kepolisian, karena keberhasilan manajemen dan yang lain itu tergantung pada kualitas sumber daya manusianya. Apabila individu dalam pemimpin. Pemimpin selain diperlukan mampu memotivasi untuk meningkatkan disiplin tetapi juga harus membina hubungan baik pada para anggota kepolisian karena dengan adanya hubungan baik tersebut, anggota kepolisian tidak merasa diperintah seperti halnya buruh dan majikan, tetapi lebih dari hubungan kemitraan atau sering juga disebut dengan hubungan kerja. Dengan adanya hubungan kepemimpinan antara atasan dan bawahan akan berfungsi dapat meningkatkan disiplin kerja serta dapat instansi yaitu SDM-nya dapat berjalan efektif maka instansi tetap berjalan efektif, dengan kata lain ketentuan kelangsungan suatu instansi kepolisian itu ditentukan oleh kinerja anggotanya. Oleh karena itu, diperlukan peran seorang mencapai tujuan yang diharapkan, selain itu ketegasan yang dimiliki seorang pemimpin juga berpengaruh besar bagi kinerja anggota kepolisian. Anggota kepolisian akan segan melanggar aturan perusahaan jika pemimpin mampu bersikap tegas ke semua anggota kepolisiannya syarat yang ditentukan, diangkat oleh pejabat. Adapun dalam Undang - Undang Kepolisian Nomor 2 Tahun 2002 pasal 1 "kepolisian adalah segala hal-ihwal yang berkaitan dengan 
fungsi dan Lembaga polisi sesuai dengan peraturan perundang - undangan".

Kinerja anggota dalam organisasi dalam suatu institusi seperti halnya kepolisian, maka peranan pimpinan merupakan salah satu kunci bagi keberhasilan dalam penyelenggaraan layanan masyarakat. Oleh karena itu untuk mewujudkan penyelenggaraan layanan institusi kepolisian bagi masyarakat maka diperlukan Kinerja setiap anggota kepolisian secara profesional. Ini berarti pimpinan di institusi kepolisian harus dapat mendorong anggotanya untuk bekerja dengan kinerja kerja yang tinggi. Dalam hal ini peran pimpinan di lingkungan kerja sangat penting. Sebagai peimpin memiliki cara yang berbeda - beda dalam mem pengaruhi bawahannya.

Adapun selain gaya kepemimpinan, kinerja kepolisian dipengaruhi oleh disiplin dari anggota itu sendiri. Kepolisian dituntut harus berdisiplin terutama disiplin waktu

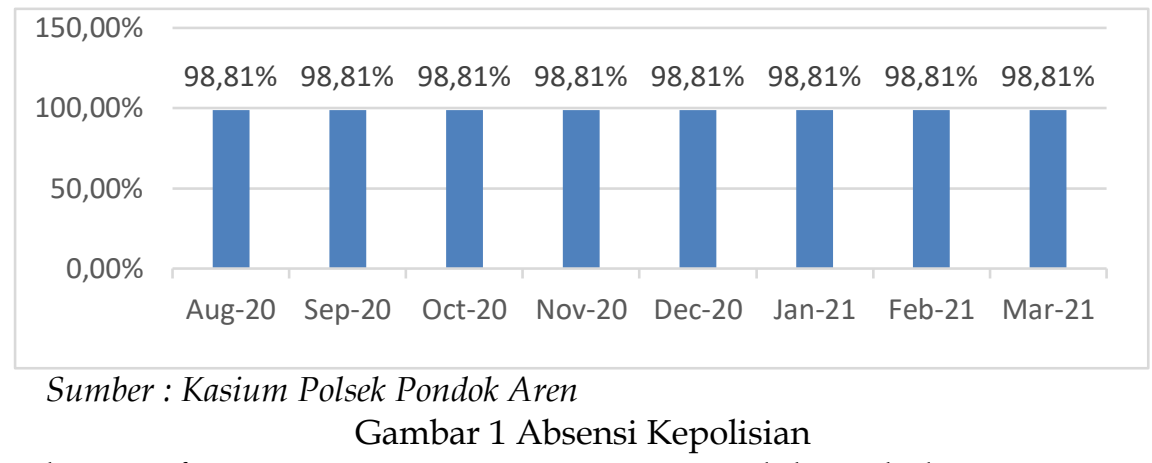

Berdasarkan informasi yang saya menandakan bahwa personil Kepolisian dapatkan dari Kasium perihal gambar 1 di Polsek Pondok Aren masuk sesuai jadwal atas terdapat satu personil kepolisian yang akan tetapi masih banyak personil selama 3 tahun tidak pernah masuk ke Kepolisian yang Telat dalam bertugas di Kantor dan sekarang sedang di proses lapangan maupun di kantor. Berikut data untuk pencabutan jabatan dari Kepolisian. rata - rata penilaian kinerja bulan Juli 2020 Walaupun dalam gambar grafik di atas sampai Maret 2021.

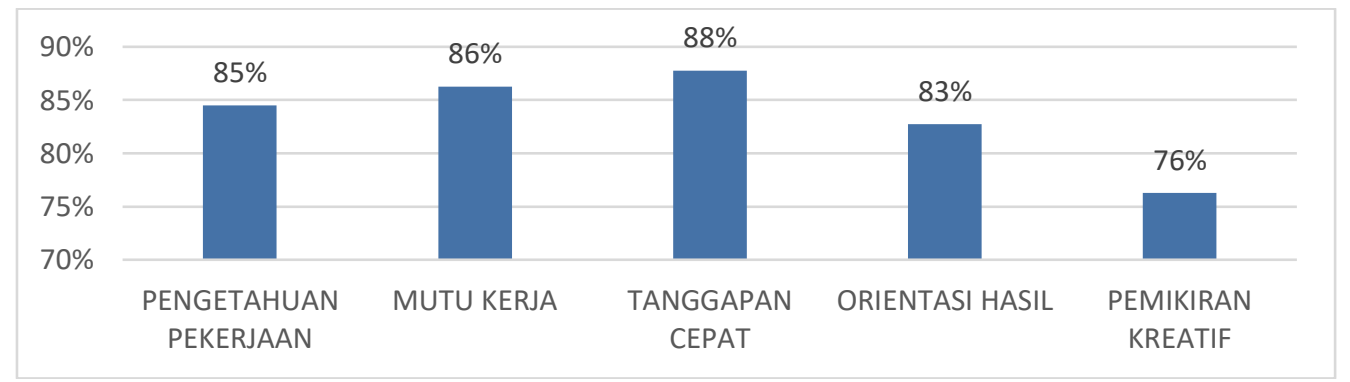

Sumber : Kasium Polsek Pondok Aren

Gambar 2 Rata - Rata Penilaian Kinerja Karyawan

Dari penilaian kinerja grafik di atas didapatkan untuk pengetahuan pekerjaan sebesar $85 \%$, mutu kerja sebesar $86 \%$, tanggapan cepat sebesar $88 \%$, orientasi hasil sebesar $83 \%$, dan pemikiran kreatif sebesar $76 \%$. Berdasarkan hasil diatas untuk penilaian kinerja kepolisian sudah bagus akan tetapi lebih baik di tingkatkan lagi untuk kinerja kepolisiannya. Dan disini peran kepemimpinan sangat penting untuk memengaruhi kinerja kepolisian lebih di tingkatkan lagi kinerja kepolisian.
Berdasarkan latar belakang yang dikemukakan diatas, maka penulis melakukan penelitian yang berjudul "Pengaruh Gaya Kepemimpinan Dan Disiplin Kerja Terhadap Kinerja Kepolisian Polisi sektor (Polsek) Pondok Aren".

\section{TINJAUAN PUSTAKA}

\section{Gaya Kepemimpinan}

Pemimpin mempunyai sifat, kebiasaan, temperamen watak dan 
kepribadian tersendiri yang khas sehingga tingkah laku dan gaya membedakan dirinya dengan orang lain. Gaya kepemimpinan adalah pola menyeluruh dari tindakan seorang pemimpin, baik yang tampak maupun yang tidak tampak oleh bawahannya. Gaya kepemimpinan menggambarkan kombinasi yang konsisten dari falsafah, keterampilan, sifat, dan sikap yang mendasari perilaku seseorang. Gaya kepemimpinan yang menunjukkan, secara langsung maupun tidak langsung, tentang keyakinan seorang pimpinan terhadap kemampuan bawahannya. Artinya gaya kepemimpinan adalah perilaku dan strategi, sebagai hasil kombinasi dari falsafah, keterampilan, sifat, sikap, yang sering diterapkan seorang pemimpin ketika ia mencoba memengaruhi kinerja bawahannya. Sehingga gaya kepemimpinan yang paling tepat adalah suatu gaya yang dapat memaksimumkan produktivitas, kepuasan kerja, pertumbuhan, dan mudah menyesuaikan dengan segala situasi.

Menurut Mulyadi (2015:150) Gaya Kepemimpinan merupakan suatu cara yang dimiliki seorang pimpinan yang menunjukkan suatu sikap yang menjadi ciri khas tertentu untuk mempengaruhi pegawainya dalam mencapai tujuan organisasi.

\section{Disiplin Kerja}

Disiplin kerja merupakan salah satu bagian dari kematangan kepribadian seseorang dan merupakan salah satu kunci untuk mencapai tujuan peruasahaan dan dapat tercapainya tujuan organisasi.

Menurut Singodimedjo dalam Edy Sutrisno (2016:86), menyatakan bahwa disiplin adalah "sikap kesediaan dan kerelaan seseorang untuk mematuhi dan menaati norma-norma peraturan yang berlaku disekitarnya." Selain itu Menurut Edy Sutrisno (2016:89) disiplin adalah "prilaku seseorang yang sesuai dengan peraturan, prosedur kerja yang ada atau disiplin adalah sikap, tingkah laku, dan perbuatan yang sesuai dengan peraturan dari organisasi baik tertulis maupun tidak tertulis". Sedangkan menurut Marwansyah (2014:410), disiplin kerja adalah "sebagai Sebuah prosedur yang mendorong karyawan untuk mengawasi perilaku mereka sendiri dan bertanggung jawab atas tindakan mereka."

Dari beberapa definisi diatas dapat disimpulkan bahwa disiplin kerja adalah sikap kesediaan karyawan untuk mematuhi peraturan-peraturan yang ada di perusahaan baik tertulis maupun tidak tertulis.

\section{Kinerja}

Menurut Rivai dan Basri dalam Masram (2015:116) kinerja adalah "hasil kerja yang dapat dicapai oleh seseorang atau kelompok orang dalam suatu perusahaan sesuai dengan wewenang dan tanggung jawab masing-masing dalam upaya pencapaian tujuan perusahaan secara legal, tidak melanggar hukum dan tidak bertentangan dengan moral dan etika". Selain itu menurut Anwar Prabu Mangkunegara (2014:9) menyatakan bahwa kinerja karyawan adalah "hasil kerja secara kualitas dan kuantitas yang dicapai oleh seseorang karyawan dalam melaksanakan tugasnya sesuai dengan tanggung jawab yang diberikan kepadanya". Sedangkan menurut Colquitt, Lepine, dan Wesson dalam Wibowo (2014:2) mengemukakan bahwa kinerja adalah "nilai serangkaian perilaku pekerja yang memberikan kontribusi, baik secara positif maupun negatif, pada penyelesaian tujuan organisasi".

Dari beberapa definisi diatas dapat disimpulkan bahwa kinerja adalah hasil akhir yang dicapai dari sekelompok orang dalam menjalankan tugasnya pada tujuan perusahaan secara legal, tidak melanggar hukum, dan tidak bertentangan dengan moral dan etika. 


\section{METODE}

Penelitian ini dilaksanakan di Polsek Pondok Aren di Jalan Graha Raya Bintaro No.3, Parigi Baru, Kec. Pondok Aren, Kota Tangerang Selatan, Banten 15222. Waktu Penelitian ini dilaksanakan selama 6 (Enam) bulan yang dimulai dari bulan Desember 2020 - Mei 2021. Populasi dalam penelitian populasinya adalah anggota Kepolisian Polisi sektor (Polsek) Pondok Aren yang berjumlah 80 anggota, teknik pengambilan sampel memakai sample jenuh, Teknik pengumpulan data menggunakan uji instrumen data, uji asumsi klasik dan uji statistic

\section{HASIL DAN PEMBAHASAN}

Berdasarkan hasil penelitian yang telah diuraikan sebelumnya menunjukkan bahwa terdapat pengaruh positif dan signifikan baik secara parsial maupun simultan gaya kepemimpinan dan disiplin kerja terhadap kinerja kepolisian. Berikut ini dipaparkan penjelasan atas jawaban dari hipotesis penelitian.

1. Pengaruh Gaya Kepemimpinan (X1)

Terhadap Kinerja kepolisian $(Y)$

Berdasarkan hasil penelitian ini didapatkan bahwa variable Gaya Kepemimpinan (X1) memiliki pengaruh terhadap Kinerja (Y) pada kepolisian Polisi sektor (Polsek) Pondok Aren. Pengaruh Gaya Kepemimpinan terhadap kinerja kepolisian dapat dijelaskan dengan beberapa faktor. Indikator gaya kepemimpinan pada pernyataan jika pekerjaan anda belum memenuhi target, pimpinan anda akan selalu memberikan pengarahan menjadi indikator skor paling rendah 3.61. Hal ini berarti untuk lebih baik lagi pimpinan diharapkan dapat memberikan arahan kepada anggotanya dengan jelas dan tegas. Hasil pengujian ini sejalan dengan beberapa penelitian terdahulu.

Hasil penelitian ini, diperoleh nilai persamaan regresi $\mathrm{Y}=14,136+0,645 \mathrm{X}_{1}$ koefisien korelasi sebesar 0,707 artinya kedua variabel mempunyai tingkat pengaruh yang kuat. Uji hipotesis diperoleh nilai $t$ hitung $>t$ tabel atau
(8.818 > 1.991), hal ini diperkuat dengan probability significancy $0.000<0.05$, dengan demikian $\mathrm{H} 0$ ditolak dan $\mathrm{H} 1$ diterima artinya terdapat pengaruh yang signifikan secara antara Gaya Kepemimpinan terhadap Kinerja kepolisian Polisi sektor (Polsek) Pondok Aren di Tangerang Selatan.

2. Pengaruh Disiplin kerja $\left(X_{2}\right)$ Terhadap Kinerja kepolisian $(\mathrm{Y})$

Berdasarkan hasil pengujian hipotesis pertama yang telah dilakukan, didapatkan bahwa variable Disiplin Kerja (X2) memiliki pengaruh terhadap Kinerja (Y) kepolisian Polisi sektor (Polsek) Pondok Aren. Pengaruh disiplin kerja dapat dilihat dari faktor disiplin kerja pada indikator pimpinan melakukan peraturan perusahaan dengan adil menjadi indikator yang paling rendah yaitu 3.37. Hal ini berarti untuk lebih baik lagi pimpinan harus bersikap adil dalam peraturan atau keputusan Hasil pengujian ini sejalan dengan beberapa penelitian terdahulu.

Hasil penelitian ini, diperoleh nilai persamaan regresi $\mathrm{Y}=13,462+0,665 \mathrm{X}_{2}$, koefisien korelasi sebesar 0.665 artinya kedua variabel mempunyai tingkat pengaruh yang kuat. Uji hipotesis diperoleh nilai $\mathrm{t}$ hitung $>\mathrm{t}$ tabel atau $(7.895>1.991)$, hal ini diperkuat dengan probability significancy $0.000<0.05$, dengan demikian $\mathrm{H} 0$ ditolak dan $\mathrm{H} 2$ diterima artinya terdapat pengaruh yang signifikan antara Disiplin kerja terhadap Kinerja kepolisian Polisi sektor (Polsek) Pondok Aren di Tangerang Selatan.

3. Pengaruh Gaya Kepemimpinan $\left(X_{1}\right)$ dan Disiplin kerja (X2) Secara Simultan

Terhadap Kinerja kepolisian (Y)

Hasil penelitian ini menunjukkan bahwa Gaya Kepemimpinan (X1) dan disiplin kerja $(\mathrm{X} 2)$ berpengaruh positif terhadap Kinerja kepolisian (Y). Pengaruh kinerja karyawan dapat dilihat dari dari indikator kinerja kepolisian pada pernyataan pekerjaan yang saya lakukan selalu di evaluasi menjadi indikator yang paling rendah yaitu 3.38. Hal tersebut berarti untuk lebih baik lagi 
pimpinan harus rutin melakukan evaluasi terhadap anggotanya agar mendapatkan hasil yang maksimal. Hasil pengujian ini sejalan dengan beberapa penelitian terdahulu.

Indikator dengan diperoleh persamaan regresi $Y=8,327+0,433 X_{1}+$ $0,364 X_{2}$. Nlai koefisien korelasi atau tingkat pengaruh antara variabel bebas dengan variabel terikat diperoleh sebesar 0,761 artinya memiliki memiliki pengaruh yang kuat. Uji hipotesis diperoleh nilai Fhitung $>$ Ftabel atau (52.913 > 2.720), hal tersebut juga diperkuat dengan probability significancy $0,000<0,05$. Dengan demikian $\mathrm{H} 0$ ditolak dan $\mathrm{H} 3$ diterima. Artinya terdapat pengaruh yang signifikan secara simultan antara Gaya Kepemimpinan dan disiplin kerja terhadap Kinerja kepolisian Polisi sektor (Polsek) Pondok Aren.

\section{PENUTUP}

\section{Kesimpulan}

Berdasarkan uraian pada bab-bab sebelumnya, dan dari hasil analisis serta pembahasan mengenai pengaruh Gaya Kepemimpinan dan Disiplin terhadap Kinerja Kepolisian, sebagai berikut :

1. Gaya kepemimpinan berpengaruh signifikan terhadap Kinerja Kepolisian dengan uji hipotesis diperoleh thitung $>$ $\mathrm{t}$ tabel atau $(8,818>1,991)$, hal ini diperkuat dengan probability signifikansi $0,000<0,05$, dengan demikian $\mathrm{H} 0$ ditolak dan $\mathrm{H} 1$ diterima artinya terdapat pengaruh signifikan antara Gaya Kepemimpinan terhadap Kinerja Kepolisian Polisi sektor (Polsek) Pondok Aren.

2. Disiplin berpengaruh signifikan terhadap Kinerja Kepolisian dengan uji hipotesis diperoleh $\mathrm{t}$ hitung $>\mathrm{t}$ tabel atau $(7,895>1,991)$, hal ini diperkuat dengan probability signifikansi $0,000<0,05$, dengan demikian $\mathrm{H} 0$ ditolak dan $\mathrm{H} 2$ diterima artinya terdapat pengaruh signifikan antara Disiplin kerja terhadap Kinerja Kepolisian Polisi sektor (Polsek) Pondok Aren.
3. Gaya Kepemimpinan dan Disiplin berpengaruh signifikan terhadap Kinerja Kepolisian dengan uji hipotesis diperoleh nilai $\mathrm{F}$ hitung $>\mathrm{F}$ tabel atau $(52,913>2,720)$, hal tersebut juga diperkuat dengan probability signifikansi $0,000<0,05$. Dengan demikian $\mathrm{H} 0$ ditolak dan $\mathrm{H} 3$ diterima. Artinya terdapat pengaruh signifikan antara Gaya Kepemimpinan dan Disiplin terhadap Kinerja Kepolisian Polisi sektor (Polsek) Pondok Aren.

\section{Saran}

Berbagai kegiatan yang dilakukan baik dari menganalisa sampai dengan menguraikan kesimpulan maka penulis mencoba memberikan saran. Dimana saran ini akan menjadi tambahan bahan evaluasi untuk perusahaan sendiri. Sebagai berikut : 1. Variabel Gaya kepemimpinan pernyataan yang paling lemah adalah nomor 10 yaitu Jika pekerjaan anda belum memenuhi target, pimpinan anda akan selalu memberikan pengarahan dimana hanya mencapai rata-rata score sebesar 3,61. Untuk lebih baik lagi pimpinan diharapkan dapat memberikan arahan kepada anggotanya dengan jelas dan tegas.

2. Variabel Disiplin kerja pernyataan yang paling lemah adalah nomor 5 yaitu Pimpinan melakukan peraturan perusahaan dengan adil dimana hanya mencapai rata-rata score sebesar 3,37. Untuk lebih baik lagi pimpinan harus bersikap adil dalam peraturan atau keputusan.

3. Variabel Kinerja kepolisian pernyataan yang paling lemah adalah nomor 3 yaitu Pekerjaan yang saya lakukan selalu di evaluasi dimana hanya mencapai ratarata score sebesar 3,38. Untuk lebih baik lagi pimpinan harus rutin melakukan evaluasi terhadap anggotanya agar mendapatkan hasil yang maksimal.

4. Untuk penelitian berikutnya disarankan untuk memperhatikan variable lain yang berpengaruh terhadap kinerja kepolisian diluar gaya kepemimpinan dan disiplin kerja selain itu juga disarankan untuk 
penelitian selanjutnya dapat diperdalam dan dilengkapi dengan kuesioner terbuka mengingat masih banyak keterbatasan dalam penelitian ini.

\section{DAFTAR PUSTAKA}

Arifin dan Barnawi. (2012). Etika dan profesi kependidikan. Jogjakarta: Ar-ruzz Media

Bintoro dan Daryanto. (2017). Manajemen Penilaian Kinerja Karyawan. Yokyakarta: Grava Media

Edison, Anwar, dan Komariyah. (2016). Manajemen Sumber Daya Manusia. Edisi Pertama. Bandung: Alfabeta

Hasibuan, Malayu S.P. (2016). Manajemen Sumber Daya Manusia. Edisi Revisi. Jakarta: Bumi Aksara.

Hermawati, R., et al. (2021). Pengaruh Pelatihan Dan Motivasi Terhadap Kinerja Karyawan Pada Bank BJB di Cabang Balaraja Banten. JENIUS (Jurnal Ilmiah Manajemen Sumber Daya Manusia), 4(3), 319-331.

Insani, P. B. E. B. (2020). Hubungan Gaya Kepemimpinan Dengan Produktivitas Kerja Pegawai Bmt El Bina Insani Cugenang. Jurnal Agrita Vol, 2(1).

Mangkunegara, AA. Anwar Prabu. (2016). Manajemen Sumber Daya Manusia Perusahaan. Bandung: PT. Remaja Rosdakarya

Marwansyah. (2014). Manajemen Sumber Daya Manusia. Edisi Kedua. Bandung: Alfabeta

Masram dan Mu'ah. (2017). Manajemen Sumber Daya Manusia. Sidoarjo: Zifatama Publiser

Mulyadi. (2015). Manajemen Sumber Daya Manusia. Jakarta: In Media

Muslimat, A., et al. (2020). Effect Of Organizational Commitment On The Sustainability Performance Of
Indonesian Industries. PalArch's

Journal of Archaeology of

Egypt/Egyptology, 17(6), 8330-8347.

Nurjaya, N., et al. (2020). Edupreneurship management in shaping the nation's character. Jurnal Konseling dan Pendidikan, 8(3), 198-206.

Rawi, R. D. P. (2017). Analisis Hubungan Motivasi Terhadap Kinerja Pegawai (Studi Kasus Pada Kantor Kecamatan Ruing Kabupaten Ngada Ntt). Jurnal Noken: Ilmu-Ilmu Sosial, 2(2), 15-28.

Riduwan. (2014). Metode dan Teknik Menyusun Tesis. Cetakan Kesepuluh. Bandung: Alfabeta

Rivai Dan Ella Sagala. (2013). Manajemen Sumber Daya Manusia Untuk Perusahaan. Jakarta: Rajawali Pers

Sugiyono. (2017). Metode Penelitian Kuantitatif, Kualitatif, dan RED. Bandung: Alfabeta, CV

Sunarsi, D. (2017). Pengaruh Kepemimpinan Dan Budaya Organisasi terhadap Kinerja Karyawan Pada Cabang Pembantu Bank DKI Pondok Labu-Jakarta Selatan. JENIUS, 1(2), 21

Sutrisno, Edy. (2016). Manajemen Sumber Daya Manusia. Jakarta: Kencana Prenada Media Group

Suwanto, S., et al. (2021). Pengaruh Motivasi Dan Pengalaman Kerja Terhadap Produktivitas Karyawan Pada Happy Restaurant Di Bandung. Jurnal Ekonomi Efektif, 3(4), 546-554.

Suwanto, S., et al.. (2021). Pengaruh Motivasi Dan Pengalaman Kerja Terhadap Produktivitas Karyawan Pada Happy Restaurant Di Bandung. Jurnal Ekonomi Efektif, 3(4), 546-554.

Wibowo, (2016). Manajemen Kinerja, Edisi Kelima. Jakarta: PT.Rajagrafindo Persada. 